\title{
Factors Affecting the Delay of Passenger Trains
}

\author{
Jana Lalinská $^{1 *}$, Jozef Gašparík ${ }^{1}$ and Denis Šipuš² \\ ${ }^{1}$ University of Zilina, The Faculty of Operation and Economics of Transport and \\ Communications, Department of Railway Transport, Univerzitná 1, 01026 Žilina, Slovak \\ Republic; Email: jana.lalinska@fpedas.uniza.sk, jozef.gasparik@fpedas.uniza.sk \\ ${ }^{2}$ University of Zagreb, Faculty of Transport and Traffic Sciences, Department of Railway \\ Transport, ZUK Borongaj, Object 70, Borongajska 83A, 10000 Zagreb, Croatia; Email: \\ denis.sipus@fpz.hr
}

\section{*Corresponding Author: Jana Lalinská}

\begin{abstract}
Paper deals with the problematic about the information quality impact and the basic methods which can optimize the costs of low quality of using information. First of all, it is important to purify the input data from the inconsistencies and measure the quality of data. This process assures to minimize the reasons that are responsible of poor quality of processes. Targets area of this paper is to identify and minimize the main reasons of delaying the passenger train by comparing years 2012 and 2013. Target groups of passenger trains were divided in three parts responsibilities of delaying - type of train, code of delay, group responsible for the train delay.
\end{abstract}

Keywords: information quality, types, reasons of delaying, passenger trains, types of delays

\section{Introduction}

Achieving the objectives and satisfying the needs of customers is the goal of any business. The fulfilment of these criteria can only be based on the accurate processing and evaluating input data that form the basis for successful decision making. Inputs of the enterprise system should be checked (e.g. by through Deming's 14 quality points, Juran trilogy, PDCA, TQM, Kaizen, TIQM) for the prevention of errors, which gives rise to poor quality information. As a result of a poor quality information is to acceptance of incorrect enterprises managers actions and achieved output distortion [1].

The aim of the article is through basic criteria for assessing the quality of information to minimize the error rate of input data which give rise to errors in the system, and which are the system works. The consistent control of input data ensures improved processes and 
minimizing excessive economic costs to eliminate mistakes. We solved the issues in the railway sector, namely by identifying factors affecting the delays of passenger trains.

\section{Basic Criteria for Controlling Input Data}

It is necessary to minimize the poor quality of information by defining the criteria, which the input data have to meet:

- complexity - information reliability growth through its complexity provision of input data; the information may not always complex but should be sufficiently comprehensive for the purpose for which it was obtained,

- relevance - relating to a specific issue,

- timeliness - data that is available on time in the correct format and structure $=$ the resulting data influence business decisions;

- accuracy - data adequately and reasonably accurate for the purpose of use; excessive accuracy of the information in the wrong place can cause problems in determining,

- clarity - correctly interpreted way the data using that ensures avoid misunderstandings,

- importance - defining the importance of information through data by eliminating nonessential data causing unnecessary distortions,

- identify the next member in the string of processing, depending on the processed input data.

If these criteria are not met, output information loses its meaning and becomes useless. Therefore, it is necessary to ensure the process of measuring the quality of input data which is intended to assess the actual condition. And, if the quality is lower than the pre-set parameters, it is necessary to find weaknesses and define measures to remedy the deficiencies.

To obtain quality information, it is necessary to use a suitable process of purifying and controlling the input data that will allow for enterprise decisions and avoid errors. For the purposes of this paper, it will deal with delays of passenger trains caused by:

- infrastructure manager - ŽSR,

- operator,

- other [2].

\section{The Quality Assessment Process of the Provided Services}

In the context of data quality, we distinguish acceptable quality of data which may contain a certain percentage of errors, however, it is sufficient to manage the organization's internal 
operational processes. At an acceptable quality of data, it leads to a situation where the additional costs to improve data quality brings little or no increase in overall quality.

Possible sources of poor quality of the data:

- errors occur when entering data into the system. They are the result of carelessness or ignorance processor. These sources of error can be minimized by pre-set standardized values,

- defects as the result of imperfection operational processes, which does not treat all the possible events and conditions,

- defects caused by imperfection of technological procedures for data processing.

The aim of data quality management is to provide the infrastructure to transform input data in consistent, accurate and reliable information. Data is generally considered to be high quality if they are fit for their intended purpose in the organizational arrangements and setting up of decisions and planning [2,3].

Data quality management is not a one-time process it is a constantly recurring process that must be accepted across the organization.

To measure the quality of data, we can use a methodology consisting of the following steps (see Fig. 1):

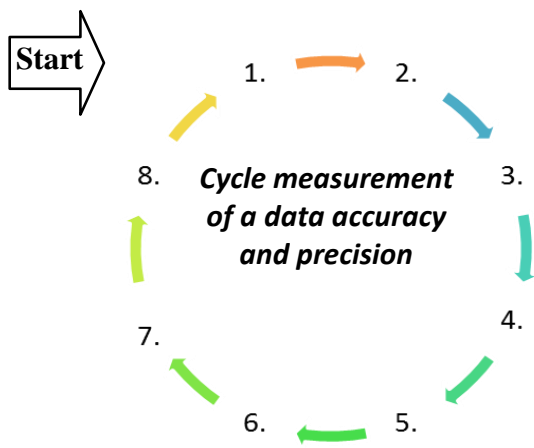

Fig. 1 Cycle of checking the correctness and accuracy of data. Source: [authors]

1. Define kinds of databases in the enterprise - on the basis of available information, are summarized information about all databases that are used in the enterprise.

2. Selection of the evaluated company database - based on the available information, is defined in the company database, which gives rise to poor quality information.

3. Define the structure of data in the database - is routine checking the composition of the database. The database may represent characters numeric, alphanumeric, audio and video, etc.

4. Selecting methods of measurement precision and accuracy of data - it is based on a performance assessment of subjective and objective criteria. To measure the 
correctness and accuracy of the data in the database, it is possible to use the method of comparison of selected, exploring the database from another database. Based on the identified deficiencies, non-compliance will be selected databases on a statistical basis expressed as a percentage of the individual errors.

5. Quantifying the costs associated with the measurement accuracy and precision data - based on the errors detected in the previous paragraph 4, will be using the method chosen (for example: Multi-criteria method) fixed costs related to the correctioncontrolled database. By quantification of the costs pertaining to the different types of costs, it will be possible to define the economic impact of poor quality data in the database.

6. Defining measures to prevent poor quality data - using appropriate remedies defined procedures that will facilitate minimize the occurrence of errors in the company. Method of controlling input data; limiting the possibility of entering data into the database; method of matching data in different databases; input will be inserted only from pre-defined values in addition to various databases; of periodically checking the accuracy of data in databases, etc.

7. Quantifying the costs related to the correction of incorrect and inaccurate data within a given step will be included in the costs of measurement accuracy and precision of data in the database, identified in paragraph 5, which will be increased by the amount of costs related to the correction of incorrect and inaccurate data.

8. Creating a database of poor quality information - the database is used to store various types of errors in the test company database, which can then be used as a support tool for the statistical measurement of the percentage of occurrence and frequency of individual errors. Based on the identified errors it is then possible to focus on identified areas of risk of errors and implement controls to minimize them [2, 4].

\section{The Evaluation Process of Information Processing}

For the transport company, it is important to record, process and evaluate the input data obtained from the system through which can then be evaluated train delays of passenger transport by:

- type of train (EC, EN, Ex, IC, Os, R, REX, Zr),

- code of delay (based on the dial train delays), 
- group responsible for the train delay (ZSR, operator, not included).

Based on the selected criteria for classification of delay, comparison of delay for the years 2012 and 2013 was processed (see Table 1). It can be stated that the number of cases of train delays increased in 2013 by 107216 cases compared with 2012, an increase in number of minutes train delays of 244,059 minutes [6].

Table 1 Comparison of delay for the years 2012 and 2013. Source: [ZSR]

\begin{tabular}{|c|c|c|c|c|c|c|c|c|}
\hline \multirow{3}{*}{$\begin{array}{l}\text { Delays } \\
\text { caused }\end{array}$} & \multicolumn{4}{|c|}{2012} & \multicolumn{4}{|c|}{2013} \\
\hline & \multicolumn{2}{|c|}{ Overall } & \multicolumn{2}{|c|}{$\begin{array}{c}\text { Expressed in percent } \\
\% \\
\end{array}$} & \multicolumn{2}{|c|}{ Overall } & \multicolumn{2}{|c|}{$\begin{array}{c}\text { Expressed in } \\
\text { percent } \%\end{array}$} \\
\hline & $\begin{array}{l}\text { Number } \\
\text { of cases }\end{array}$ & $\begin{array}{l}\text { Number of } \\
\text { minutes }\end{array}$ & $\begin{array}{l}\text { Number of } \\
\text { cases }\end{array}$ & $\begin{array}{l}\text { Number } \\
\text { of minutes }\end{array}$ & $\begin{array}{l}\text { Number } \\
\text { of cases }\end{array}$ & $\begin{array}{l}\text { Number of } \\
\text { minutes }\end{array}$ & $\begin{array}{l}\text { Number } \\
\text { of cases }\end{array}$ & $\begin{array}{l}\text { Number } \\
\text { of minutes }\end{array}$ \\
\hline Operator & 137383 & 297138 & $24.74 \%$ & $16.45 \%$ & 117090 & 260663 & $17.67 \%$ & $12.72 \%$ \\
\hline Not included & 240196 & 1062447 & $43.25 \%$ & $58.84 \%$ & 310793 & 1241538 & $46.91 \%$ & $60.57 \%$ \\
\hline ZSR & 177745 & 446184 & $32.01 \%$ & $24.71 \%$ & 234657 & 547627 & $35.42 \%$ & $26.72 \%$ \\
\hline Sum & 555324 & 1805769 & $100.00 \%$ & $100.00 \%$ & 662540 & 2049828 & $100.00 \%$ & $100.00 \%$ \\
\hline
\end{tabular}

Comparing the years 2012 and 2013, it can be stated that the number of cases of train delays caused by carriers fell by $7.07 \%$, a $3.74 \%$ decrease in the number of minutes delay. In contrast, the number of cases of delays caused by ZSR increased by $3.41 \%$, an increase of $2.01 \%$, and the number of cases identified as not included increased by $3.66 \%$, an increase in the percentage of minutes of $1.73 \%$.

The closer classified delays for different types of passenger trains (see Table 2) compared 2012 and 2013, passenger trains cover the largest ratio of numbers of delays cases but by comparing the years 2012 and 2013, it can be stated that the number of cases of delays fell by $1.7 \%$, which represents a decrease in the percentage of minutes by $0.77 \%$ [7]. 
Table 2 Comparison the train delay per type of 2012 and 2013. Source: [ZSR]

\begin{tabular}{|c|c|c|c|c|c|c|c|c|}
\hline \multirow{3}{*}{$\begin{array}{l}\text { Type } \\
\text { of } \\
\text { train }\end{array}$} & \multicolumn{4}{|c|}{2012} & \multicolumn{4}{|c|}{2013} \\
\hline & \multicolumn{2}{|c|}{ Overall } & \multicolumn{2}{|c|}{$\begin{array}{c}\text { Expressed in percent } \\
\% \\
\end{array}$} & \multicolumn{2}{|c|}{ Overall } & \multicolumn{2}{|c|}{$\begin{array}{c}\text { Expressed in percent } \\
\%\end{array}$} \\
\hline & $\begin{array}{l}\text { Number of } \\
\text { cases }\end{array}$ & $\begin{array}{l}\text { Number of } \\
\text { minutes }\end{array}$ & $\begin{array}{l}\text { Number of } \\
\text { cases }\end{array}$ & $\begin{array}{c}\text { Number of } \\
\text { minutes }\end{array}$ & $\begin{array}{l}\text { Number of } \\
\text { cases }\end{array}$ & $\begin{array}{c}\text { Number } \\
\text { of minutes }\end{array}$ & $\begin{array}{l}\text { Number } \\
\text { of cases }\end{array}$ & $\begin{array}{c}\text { Number of } \\
\text { minutes }\end{array}$ \\
\hline EC & 96690 & 19578 & $5.33 \%$ & $3.53 \%$ & 119517 & 21214 & $5.83 \%$ & $3.20 \%$ \\
\hline EN & 19685 & 3813 & $1.08 \%$ & $0.69 \%$ & 22022 & 3663 & $1.07 \%$ & $0.55 \%$ \\
\hline Ex & 65674 & 15320 & $3.62 \%$ & $2.76 \%$ & 59624 & 16733 & $2.91 \%$ & $2.52 \%$ \\
\hline IC & 38272 & 17630 & $2.11 \%$ & $3.17 \%$ & 47589 & 21535 & $2.32 \%$ & $3.25 \%$ \\
\hline OS & 1179935 & 338182 & $64.98 \%$ & $60.90 \%$ & 1297238 & 398817 & $63.28 \%$ & $60.13 \%$ \\
\hline $\mathrm{R}$ & 304086 & 122962 & $16.75 \%$ & $22.14 \%$ & 331385 & 136424 & $16.17 \%$ & $20.57 \%$ \\
\hline REX & 36024 & 9753 & $1.98 \%$ & $1.76 \%$ & 127276 & 50129 & $6.21 \%$ & $7.56 \%$ \\
\hline $\mathrm{Zr}$ & 75390 & 28083 & $4.15 \%$ & $5.06 \%$ & 45226 & 14792 & $2.21 \%$ & $2.23 \%$ \\
\hline Sum & 1815756 & 555321 & $100.00 \%$ & $100.00 \%$ & 2049877 & 663307 & $100.00 \%$ & $100.00 \%$ \\
\hline
\end{tabular}

The most common reason for train delays in 2012 were the codes: $12,13,14,15,16,19$, $22,24,25,29,31,33,39,41,42,43,49,50,52,59,60,61,63,64,72,74,80,82,84,85,86$, 89,95 . The most common reason for train delays in 2013 were the codes:

$11,12,13,14,15,16,22,24,25,29,31,33,39,41,42,43,49,50,52,59,60,61,63,64,72$, $74,80,84,85,86,89$.

Table 3 Comparison the train delay by delays code in 2012 and 2013. Source: [ZSR]

\begin{tabular}{|c|c|c|c|c|c|c|c|c|}
\hline \multirow[b]{2}{*}{ 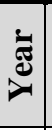 } & \multirow[b]{2}{*}{ Reason of delay } & \multirow[b]{2}{*}{$\begin{array}{l}\text { Code } \\
\text { delay }\end{array}$} & \multirow[b]{2}{*}{$\begin{array}{l}\text { Responsible } \\
\text { group }\end{array}$} & \multirow[b]{2}{*}{$\begin{array}{l}\text { Type } \\
\text { of train }\end{array}$} & \multicolumn{2}{|c|}{2012} & \multicolumn{2}{|c|}{2013} \\
\hline & & & & & $\begin{array}{l}\text { Number } \\
\text { of cases }\end{array}$ & $\begin{array}{c}\text { Number } \\
\text { of minutes }\end{array}$ & $\begin{array}{l}\text { Number } \\
\text { of cases }\end{array}$ & $\begin{array}{c}\begin{array}{c}\text { Number of } \\
\text { minutes }\end{array} \\
\end{array}$ \\
\hline \multirow{3}{*}{$\frac{\mathfrak{z}}{\overline{\mathcal{z}}}$} & $\begin{array}{l}\text { Other transport } \\
\text { reasons }\end{array}$ & 19 & ŽSR & OS & 76 & 793 & 62 & 627 \\
\hline & Other railways & 82 & not included & $\mathrm{EC}$ & 3765 & 45251 & 4202 & 65961 \\
\hline & $\begin{array}{l}\text { further investigation } \\
\text { is needed }\end{array}$ & 95 & ŽSR & OS & 52 & 113 & 6644 & 11973 \\
\hline$\frac{m}{\bar{\tau}}$ & $\begin{array}{l}\text { Exceeding driving } \\
\text { times }\end{array}$ & 11 & ŽSR & OS & 139 & 303 & 86 & 144 \\
\hline
\end{tabular}

\section{Conclusion}

Based on a comparison of development of delay reasons of passenger transport in 2012 and 2013, the number of cases of delays increased in almost every category. Decline due to a delay occurred only in the categories of Ex and Zr. The highest increase in the number of cases of delays in 2013 compared to 2012 was in the category of trains REX about 91,252, which represents $4.23 \%$ increase in the number of cases of delays.

In 2013, delays were reduced by reason of the reasons 19 - other transport reasons, 82 - 
other railways 95 - further investigation are needed, which were due on the part of ZSR and not included in the offender. In contrast, in 2013 the number has increased due to a delay in categories 11 - exceeding driving time.

\section{Acknowledgements}

The paper is supported by the VEGA Agency by the Project 1/0095/16 "Assessment of the quality of connections on the transport network as a tool to enhance the competitiveness of public passenger transport system" that is solved at Faculty of Operations and Economics of Transport and Communication, University of Žilina.

This paper is prepared with the support of the project "Transfer of innovative knowledge and technology in logistics and transport processes“, ITMS project code 26220220006, University of Žilina.

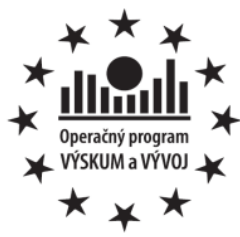

$$
\text { ERDF - Európsky fond regionálneho rozvoja }
$$

\section{Projekt je spolufinancovaný zo zdrojov ES}

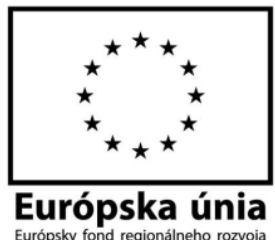

„Podporujeme výskumné aktivity na Slovensku/Projekt je spolufinancovaný zo zdrojov EÚ.“

\section{References}

[1] Nedeliaková, E., Panák, M. \& Štefancová, V. (2016). Qualitative approaches to increasing the efficiency of capacity in intermodal transport. Perner's Contacts, 11(3), 131-138.

[2] Dolinayova, A., Camaj, J. \& Danis, J. (2016). Evaluation of investment efficiency in the new database solution for rail freight transort in the context of globalization. In 16th International Scientific Conference on Globalization and its Socio-Economic Consequences, Rajecke Teplice, Slovakia: University of Žilina, Faculty of operation and economics of transport and communications, Slovak Republic, October 05-06. 2016, 383 390.

[3] Černá, L., Zitrický, V. \& Ponický, J. (2016). Income and price elasticity of demand for transport services in rail passenger transport in the Slovak. In Mathematical methods in economics - MME 2016: 34th international conference: Liberec, Czech Republic: Technical university of Liberec, September 06.-09. 2016, 126-131.

[4] Masek, J., Camaj, J. \& Belosevic, I. (2016). Improving the transport capacity of the intermodal train and track based on different types of wagons. In $3^{\text {rd }}$ International 
Conference on Traffic and Transport Engineering (ICTTE), November 24.-25. 2016 (pp 409-416), Belgrade, Serbia: Scientific research centre Ltd., Belgrade, Serbia

[5] Buková, B., Brumerčíková, E. \& Kondek, P. (2016). Impact of population development and employment on the transport performance in the EU. In $3^{\text {rd }}$ International Conference on Traffic and Transport Engineering (ICTTE), Belgrade, Serbia: Scientific research centre Ltd., Belgrade, Serbia, November 24.-25, 2016, 937-940.

[6] Milinković, S., Marković, M., Vesković, S., Ivić, M. and Pavlović, N., 2013. A fuzzy Petri net model to estimate train delays. Simulation Modelling Practice and Theory, 33, pp.144-157.

[7] Marković, N., Milinković, S., Tikhonov, K.S. and Schonfeld, P., 2015. Analyzing passenger train arrival delays with support vector regression. Transportation Research Part C: Emerging Technologies, 56, pp.251-262. 